\title{
Song-related dopamine receptor regulation in Area X of zebra finch male
}

\author{
Eva Bosíková, Lubor Koštál, Martina Cviková, Boris Bilč́k and Lubica Niederová-Kubíková \\ Laboratory of Neurobiology and Physiology of Behaviour, Institute of Animal Biochemistry and Genetics, Slovak Academy of \\ Sciences, Ivanka pri Dunaji, Slovak Republic
}

\begin{abstract}
Song learning and production have many parallels with speech and the mechanisms of their control have been studied extensively. There is an increasing amount of evidence that the dopaminergic system is involved in song learning and maintenance. Dopamine receptors show distinct expression in most of the song nuclei and the highest levels in Area X of the striatum. Here we have investigated whether the mRNA expressions for D1A, D1B, and D2 receptors in Area $X$ are associated with quantitative and/or qualitative characteristics of zebra finch song. We found that quantitative parameters of song such as the amount of songs sang, motif duration, and numbers of distinct syllables and/or notes per motif did not correlate with expression of D1A, D1B nor D2 receptors in Area X or surrounding striatum. However, the mean accuracy of the song correlated negatively with D1A receptor expression levels and the sequential match correlated positively with D2 receptor expression levels in Area X relative to the surrounding striatum. These data suggest that dopamine receptor densities in Area X are associated with song variability.
\end{abstract}

Key words: Striatum — Mean accuracy — Sequential match — mRNA

\section{Introduction}

Dopamine is one of the key neurotransmitters in brain having regulatory role in motor functions, emotions, motivation, and cognition in mammals, as well as in birds (Durstewitz et al. 1999; Nieoullon and Coquerel 2003). It exerts its functions via dopamine receptors (Missale et al. 1998), whose distribution in avian brain has been mapped using binding techniques and in situ hybridization histochemistry (Richfield et al. 1987; Dietl and Palacios 1988; Casto and Ball 1994; Ball et al. 1995; Schnabel and Braun 1996; Sun and Reiner 2000; Kubikova et al. 2010). Birds possess, similarly as mammals, D1A (called also D1), D1B (D5), D2, D3, and $\mathrm{D} 4$ dopamine receptors, and D1D receptor unique to birds. They are widely located in specific areas of the avian brain and they also show a special distribution among song nuclei that control vocal learning and production in songbirds (Kubikova et al. 2010).

Correspondence to: Lubica Niederová-Kubíková, Laboratory of Neurobiology and Physiology of Behaviour, Institute of Animal Biochemistry and Genetics, Slovak Academy of Sciences, Moyzesova 61, 90028 Ivanka pri Dunaji, Slovak Republic

E-mail: Lubica.Kubikova@savba.sk
Vocal learning is a rare trait in animal kingdom and songbirds often serve as a neurobiological model to study mechanisms of vocal learning for parallels in song and speech acquisition (Brainard and Doupe 2002). Learning and production of learned song patterns in songbirds is controlled by an anatomically discrete system of interconnected brain nuclei (Nottebohm et al. 1976). The nucleus residing in songbird basal ganglia, Area X, receives the densest dopaminergic innervations among all song nuclei from the midbrain ventral tegmental area (VTA) and substantia nigra, pars compacta (SNc) (Lewis et al. 1981; Person et al. 2008). It also shows the highest expressions of the D1A, D1B, and D2 dopamine receptor mRNAs and these levels are higher than those in the surrounding striatum (Kubikova et al. 2010).

The role of dopamine receptors in Area X or in any of the song nuclei in song learning and maintenance is not known yet. Dopamine levels in Area $\mathrm{X}$ as well as gene expression and electrical activity of neurons in Area X depend on social context of the song, i.e. they differ when the male sings undirected song while being alone and when he sings directed song to a female during courtship (Hessler and Doupe 1999a; Jarvis et al. 1998; Sasaki et al. 2006). Undirected song is necessary for song learning and maintenance but it does not result in any obvious immediate social reinforcement. Riters 
(2011) proposed that this form of song may be intrinsically reinforced. The act of producing undirected song may induce a rewarding neural state, i.e. dopamine is expected to trigger song, whereas opioids are expected to maintain undirected song. Possible role of the dopamine receptors regulation in these processes is unclear.

The aim of this study was to test whether age, quantitative parameters of undirected song structure, including singing duration, number of song bouts, number of distinct syllables per song motif, number of distinct notes per motif, motif duration, and the parameters of song variability, i.e. similarity score, percentage of similarity, mean accuracy, and sequential match, are related to the D1A, D1B, and D2 receptor densities in Area $\mathrm{X}$ and striatum of zebra finch male.

\section{Materials and Methods}

\section{Animals}

Twenty two male zebra finches (Taeniopygia guttata) were used in this study. The birds were 83 to 1007 days old (480.9 \pm 53.7 days, mean \pm SEM). They were kept on a 14:10 light/ dark cycle, food and water were provided ad libitum, and the birds were housed in sound attenuating boxes for two weeks before sacrifice.

The experiments were performed in accordance with the Slovak law and the corresponding EU regulations and were approved by the Institutional Animal Care and Use Committee and the State Veterinary and Food Administration of the Slovak Republic.

\section{Behaviour}

On the last day, the birds were allowed to sing for $1 \mathrm{~h}$ after the lights were turned on and the onset of singing. The songs were recorded and later analysed using the Sound Analysis Pro 2.062 software (Tchernichovski et al. 2000). Song is organized in a hierarchical manner: syllables - distinct song elements that can consist of one or more notes and are separated by at least $5 \mathrm{~ms}$ silent intervals, motifs - stereotyped sequences of syllables, and bouts - periods of singing separated by silent intervals at least $2 \mathrm{~s}$ long (Sossinka and Böhner 1980). Two independent observers quantified the following measures from all songs sang during the one hour after the onset of singing on the day of sacrifice and at two other days before sacrifice within two weeks before: the number of song bouts, the number of distinct syllables per motif, and the number of distinct notes per motif. There were only minor differences between the observers and in case of differences the observers reached the consensus value after discussion. The singing duration was also calculated in the same songs. Further, motif variability was assessed by meas- uring four parameters of similarity provided by the Sound Analysis Pro software: score, percentage of similarity, mean accuracy, and sequential match. They were calculated from 10 comparisons of randomly selected pairs of motifs from songs sang during the same one hour periods as explained above. Lastly, motif duration was quantified from the first 20 motifs sang on the three measured days.

\section{In situ hybridization}

After behavioural observation the males were sacrificed by decapitation, their brains were quickly dissected, frozen in optimum cutting temperature (OCT) embedding compound (Sakura Finetek, Japan) in the embedding molds (Peel-AWay, Polysciences, USA), and stored at $-20^{\circ} \mathrm{C}$ until they were cut.

Sagittal sections from left hemispheres containing the song nucleus Area X and striatum were cut on the cryocut Leica CM 1800 (Reichert-Jung, USA). The $10 \mu \mathrm{m}$ thick sections were mounted onto silanized glass slides and stored at $-80^{\circ} \mathrm{C}$. Riboprobes for D1A, D1B, and D2 dopamine receptors were labelled using ${ }^{35} \mathrm{~S}$-UTP and prepared according to the protocol of Kubikova and co-authors (Kubikova et al. 2010). The reaction mixture $(10 \mu \mathrm{l})$ composed of $1 \mu \mathrm{l}$ of diethyl pyrocarbonate (DEPC) water, $0.15 \mu \mathrm{g}$ of particular DNA fragment, $1 \mu \mathrm{l}$ of $10 \times$ RNA transcription buffer, $0.5 \mu \mathrm{l}$ of $0.1 \mathrm{M}$ dithiothreitol (DTT), $0.5 \mu \mathrm{l}$ of RNase inhibitor, $1.5 \mu \mathrm{l}$ of AGC nucleotides (ATP, GTP, CTP) mix, $3 \mu$ of ${ }^{35}$ S-UTP (Perkin-Elmer Life Sciences, USA), and $1 \mu \mathrm{l}$ of RNA polymerase. It was incubated for 2 hours at $37^{\circ} \mathrm{C}$ and precipitated after addition of $40 \mu \mathrm{l}$ DEPC water, $5 \mu \mathrm{l}$ of $3 \mathrm{M}$ sodium acetate, and $125 \mu \mathrm{l}$ of $100 \%$ ethanol. Before hybridization, the sections were fixed in 3\% paraformaldehyde for $5 \mathrm{~min}$, rinsed $3 \times 1 \mathrm{~min}$ in PBS ( $\mathrm{pH} \mathrm{7.4)}$ ), acetylated for $10 \mathrm{~min}$ in $1.36 \%$ triethanolamine and $0.252 \%$ acetic anhydride solution, rinsed $3 \times 1$ min in $2 \times \mathrm{SSPE}$ buffer (containing $\mathrm{NaCl}, \mathrm{NaH}_{2} \mathrm{PO}_{4}$, and ethylenediaminetetraacetate), and finally dehydrated in $70 \%, 95 \%$, and $100 \%$ ethanol for $2 \mathrm{~min}$ in each. The tissue on slides was covered with $100 \mu \mathrm{l}$ of hybridization solution with the appropriate amount of riboprobes to obtain the final concentration of $10^{6} \mathrm{cpm}$ per slide, coverslipped, and hybridized overnight (12-20 hours) in mineral oil bath at $64^{\circ} \mathrm{C}$. On the next day, the slides were shortly washed in xylene, and the sections were incubated for $1 \mathrm{~h}$ at room temperature in $2 \times$ SSPE buffer with $0.1 \%$ mercaptoethanol, $1 \mathrm{~h}$ at $64^{\circ} \mathrm{C}$ in $2 \times$ SSPE buffer containing $50 \%$ formamide and $0.1 \%$ mercaptoethanol, and 2 times for $30 \mathrm{~min}$ at $64^{\circ} \mathrm{C}$ in $0.1 \times \mathrm{SSPE}$ buffer. The sections were then dehydrated in 70\%, 95\%, and $100 \%$ ethanol for $2 \mathrm{~min}$ in each, and apposed to X-ray film (Kodak BioMax MR, Perkin-Elmer Life Sciences, USA) for 3 days (D1A and D1B) or 2 days (D2). The in situ hybridizations for one receptor subtype were performed at the same time and the sections for each receptor were apposed to one film. 


\section{Quantification and statistics}

The expression levels of D1A, D1B, and D2 dopamine receptor mRNAs were quantified from the X-ray films. The images were digitized using Canon EOS 40D camera with Canon EF $100 \mathrm{~mm}$ f/2.8 USM Macro lens (Canon, Japan) and Kaiser Slimlite B lightbox (Kaiser Fototechnik, Germany). The mean optical densities of Area X, surrounding striatum, and the film immediately adjacent to the measured areas in the brain were quantified using the ImageJ software (Abramoff et al. 2004). The background optical density of film was subtracted from the receptor densities in the Area X and striatum and the ratio of expression in Area $\mathrm{X}$ and the surrounding striatum (Area X/striatum) were calculated.

The age, the quantitative parameters of undirected song structure, including singing duration, number of song bouts, number of distinct syllables per motif, number of distinct notes per motif, motif duration, and the parameters of the song variability, i.e. similarity score, percentage of similarity, mean accuracy, and sequential match were related to the $\mathrm{D} 1 \mathrm{~A}, \mathrm{D} 1 \mathrm{~B}$, and $\mathrm{D} 2$ receptor densities in Area X, striatum, and Area $\mathrm{X} /$ striatum ratio. The strength of the association between the two variables was estimated by the Pearson's correlation coefficient. Statistical analyses were performed using SigmaPlot 11 (Systat Software Inc., USA).

\section{Results}

Dopamine receptors expression in relation to age

All three dopamine receptor subtypes studied, D1A, D1B, and D2, had high mRNA expressions in striatum and even higher in Area X (Fig. 1). The ratios of expressions in Area $\mathrm{X}$ to striatum were $1.36 \pm 0.04$ (mean $\pm \mathrm{SEM}$ ) for D1A, $1.19 \pm 0.02$ for $\mathrm{D} 1 \mathrm{~B}$, and $1.41 \pm 0.04$ for $\mathrm{D} 2$ receptors.

Dopamine receptor mRNAs levels did not change with age in birds that aged between 83 and 1007 days (Fig. 2) neither in Area X, nor in striatum, as indicated by linear regression analysis. The ratio of expression in Area X to striatum also did not correlate with the age of the birds.

Dopamine receptors expression in relation to song structure

On the day of sacrifice the birds sang up to 98 song bouts $(30.47 \pm 5.27$, mean \pm SEM) and spent up to $409.75 \mathrm{~s}$ by
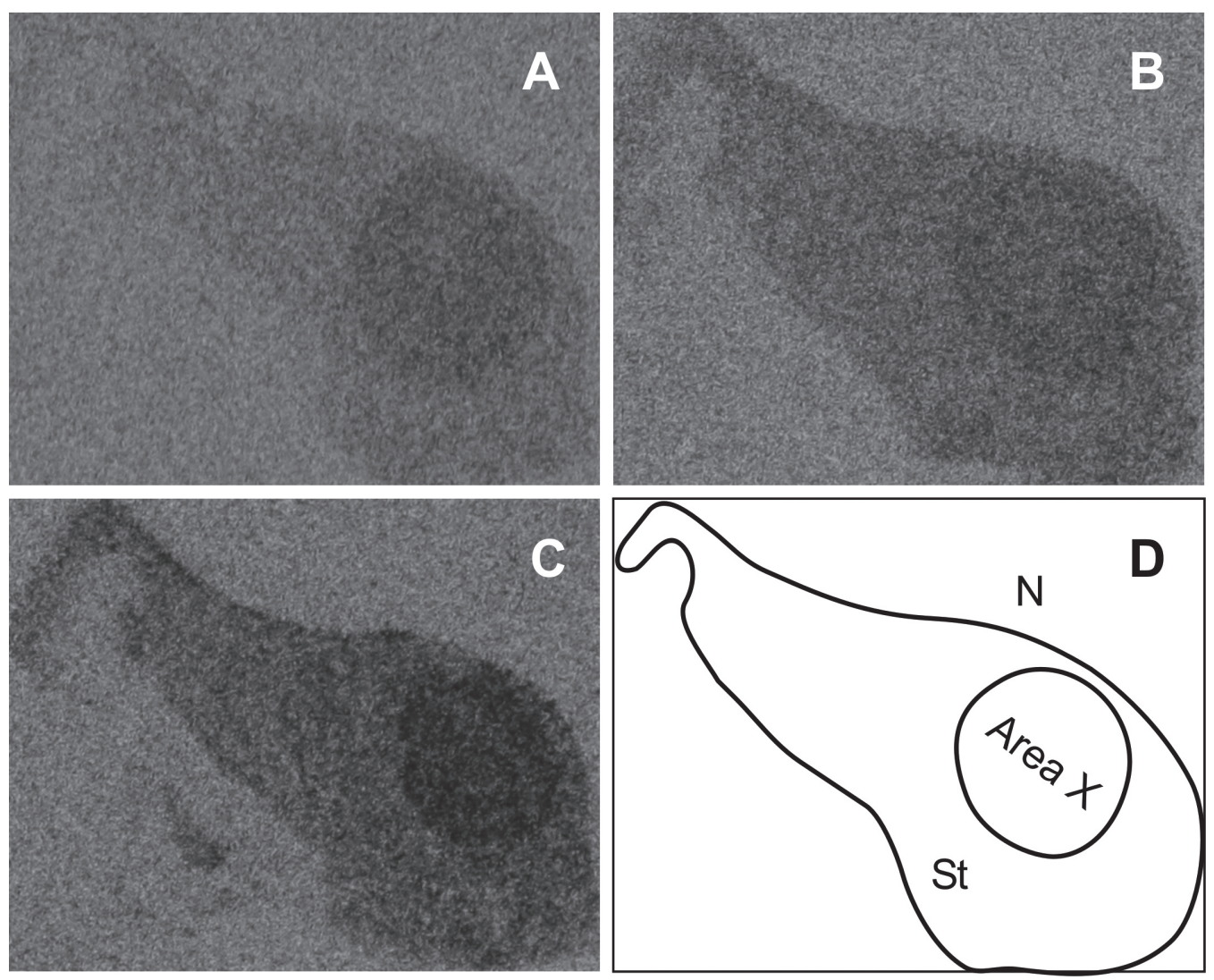

Figure 1. Representative autoradiograms of the mRNA expression of the D1A (A), D1B (B) and D2 (C) dopamine receptors in striatum and Area X of zebra finch male and the schematic view of the region (D). N, nidopallium; St, striatum. 
singing (106.42 $\pm 24.35 \mathrm{~s})$ during the last $1 \mathrm{~h}$ period. None of these factors was associated with the expression of D1A, $\mathrm{D} 1 \mathrm{~B}$, or $\mathrm{D} 2$ receptors.

Further we compared the time spent by singing during the first hour of singing on the last day with two other days before sacrifice. We found that the time spent by singing correlated positively among these three days $(p=0.05$ to $p<0.001 ; \mathrm{r}=0.61-0.93)$. When averaged the time spent by singing during the three days, we did not find any significant correlation between the dopamine receptor densities and singing duration in Area X, striatum, or the ratio of expressions in Area X and striatum (Fig. 3).
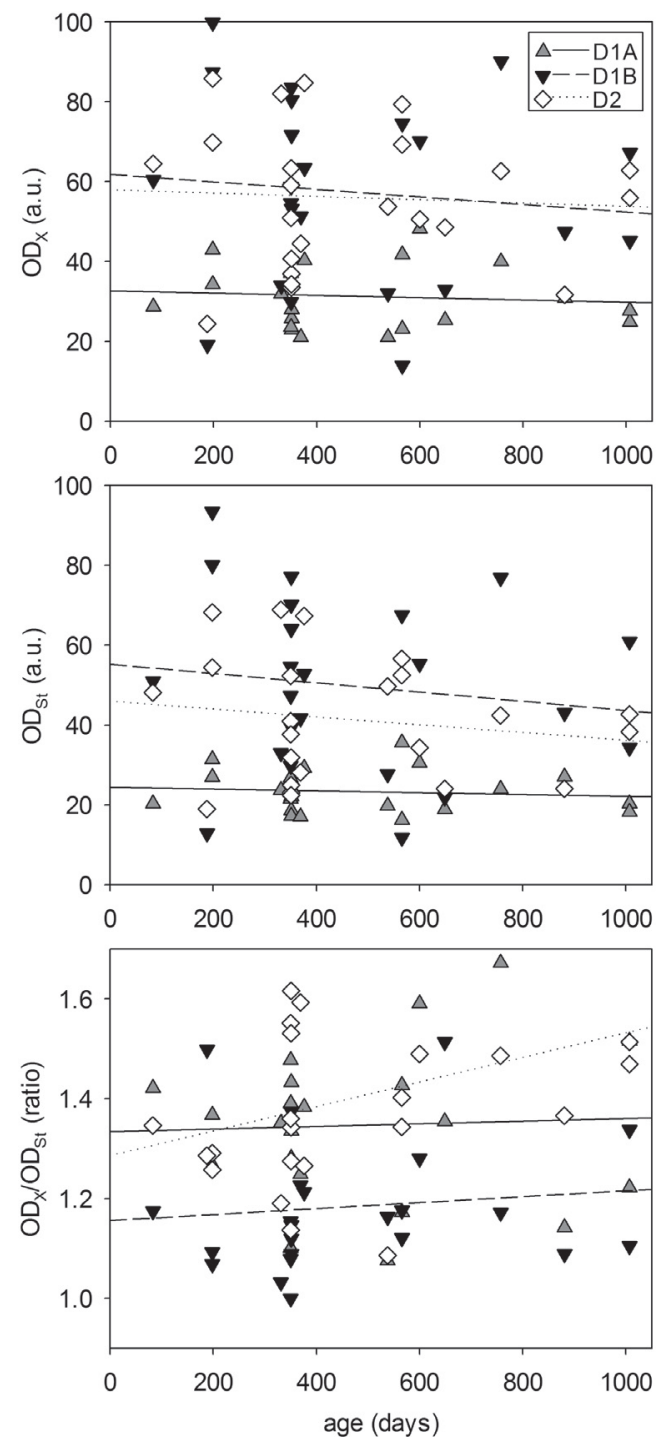

Figure 2. Expression of the D1A, D1B and D2 receptor mRNAs in Area $\mathrm{X}$, striatum and the ratio of the $\mathrm{X} / \mathrm{St}$ expression in relation to age $(n=22)$. OD $D_{\mathrm{X}}$ : optical density in Area X; OD ${ }_{\mathrm{St}}$ : optical density in striatum.
We found that the number of distinct syllables used by an individual (2-8) and the number of distinct notes within motif (4-15) was the same during the 3 days in which the songs were analysed. The motif length (250-1009 ms) did not change significantly among these days either. Means of these parameters for the 3 days did not correlate significantly with $\mathrm{D} 1 \mathrm{~A}, \mathrm{D} 1 \mathrm{~B}$, or $\mathrm{D} 2$ receptor densities in the measured areas (Fig. 4 for motif length).

\section{Dopamine receptor expression in relation to song variability}

Finally, we have related the measures of motif variability with the dopamine receptor expressions. We found that the mean accuracy correlated negatively with the intensity of D1A dopamine receptor mRNA expression in Area X/striatum (Fig. 5). We also found a positive correlation of the sequential match and the intensity of $\mathrm{D} 2$ receptor $\mathrm{mRNA}$ expression in Area X/striatum (Fig. 6). The other measures of variability were not associated with the dopamine receptor densities in the measured areas.

\section{Discussion}

Dopaminergic neurotransmission has been implied to play a role in birdsong in many studies (for review see Kubikova and Kostal 2010). The expression patterns of the D1A, $\mathrm{D} 1 \mathrm{~B}$, and $\mathrm{D} 2$ receptor mRNAs reported here correspond with the previously published data in adult songbirds using in situ hybridization (Kubikova et al. 2010) and receptor binding (Casto and Ball 1994). Here we studied association of dopamine receptors rich in the vocal nucleus Area X of striatum with various parameters of song. We found that not quantitative but qualitative parameters of song are associated with changes in dopamine receptor densities in Area X relative to the surrounding striatum. Bellow we discuss the implications of these findings.

\section{Dopamine receptors expression in relation to age}

There is a general pattern of age-related alteration in striatal dopamine D1 and D2 receptors expression and binding, characterized by an initial increase in an early postnatal life, than reaching a peak followed by gradual decline (Reeves et al. 2002). It may be applicable to a wide range of species ranging from Aplysia (Chandhoke et al. 2001), through rats (Henry et al. 1986; Teicher et al. 1995) to humans (Suhara et al. 1991; Antonini et al. 1993; Meng et al. 1999).

Dopamine D1A and D1B receptors within Area X in juvenile zebra finch males up to 75 days of age showed initial increases followed by decreases in absolute expression levels, whereas D2 exhibit a gradual increase into adulthood (Kubikova et al. 2010). Similar results were found in the sur- 
rounding striatum. The present study involving age group of zebra finch males from 83 days to 2.8 years did not indicate any dramatic age-related changes in dopamine receptor subtypes expressions. Their levels seem to be relatively stable during the studied period, although we can see moderate age-dependent decline in the D1B and D2 receptors expression in both Area $\mathrm{X}$ and surrounding striatum.

\section{Dopamine receptors expression in relation to song structure}

Although immediate early gene expression and activity in Area $\mathrm{X}$ are strongly related to the amount of songs produced (Jarvis and Nottebohm 1997; Hessler and Doupe
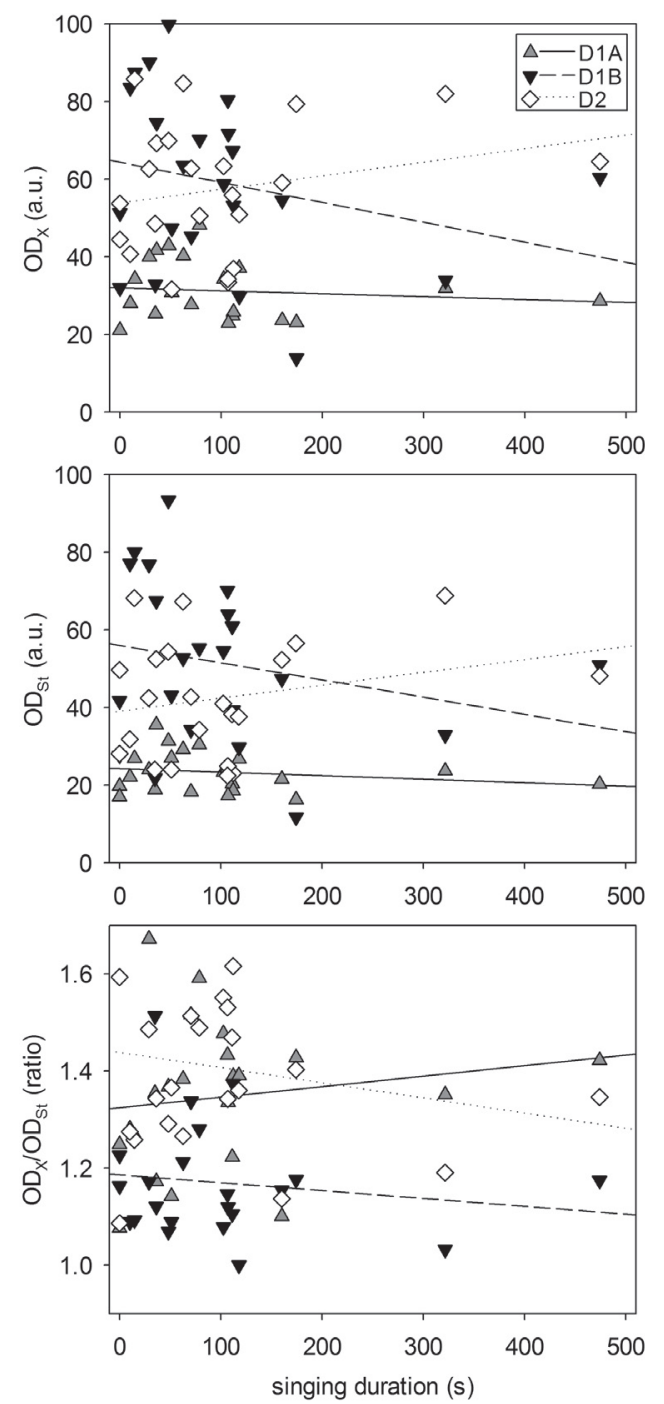

Figure 3. Expression of D1A, D1B and D2 receptor mRNAs in Area $\mathrm{X}$, striatum and the ratio of the $\mathrm{X} / \mathrm{St}$ expression in relation to singing duration (mean of the data from one hour before the sacrifice and one hour after the onset of singing on two other days) $(n=22)$. $\mathrm{OD}_{\mathrm{X}}$ : optical density in Area X; $\mathrm{OD}_{\mathrm{St}}$ : optical density in striatum. 1999b; Kubikova et al. 2007) we did not find a significant correlation between the singing duration, the number of distinct syllables, the number of distinct notes within motif or motif length and dopamine receptor expressions in this song nucleus. Similarly, Sasaki et al. (2006) did not find a significant correlation between dopamine levels and the amount of female-directed or undirected zebra finch male song produced per $10 \mathrm{~min}$ bin. Heimovics and Riters (2008) found in starlings that measures of thyrosine hydroxylase (the rate-limiting enzyme in catecholamine synthesis) correlated with song produced within, but not
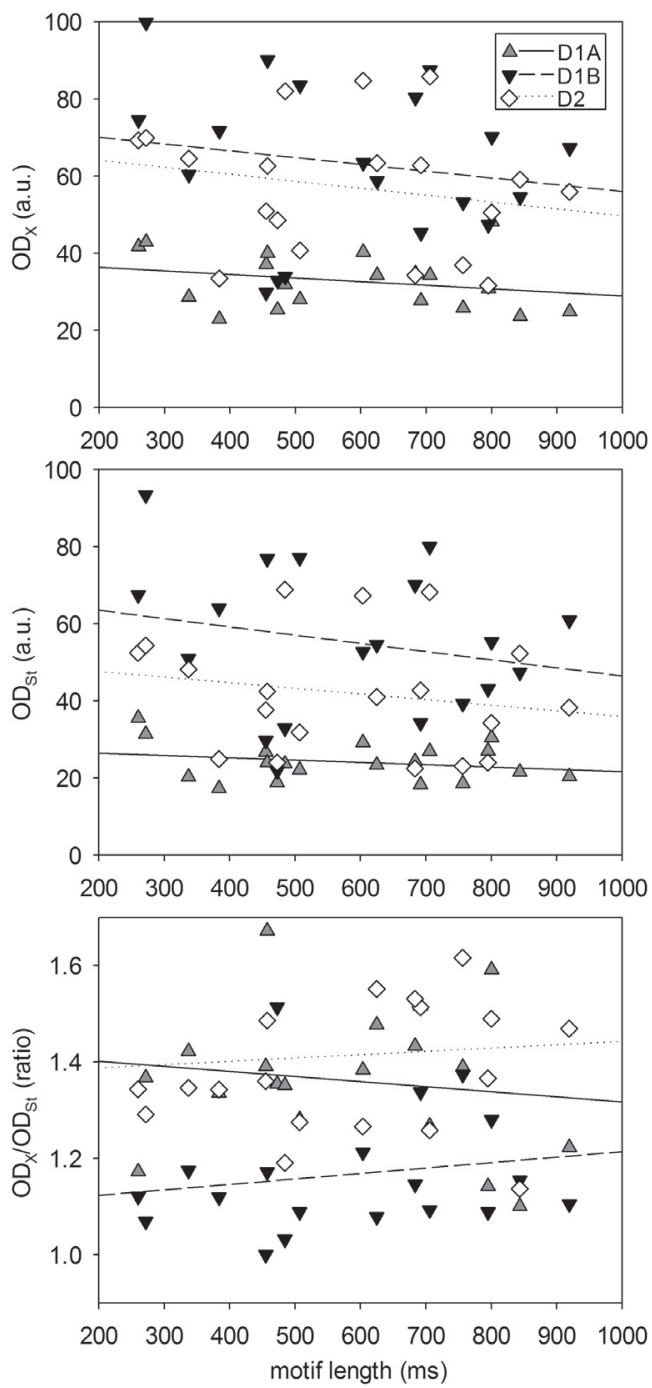

Figure 4. Expression of D1A, D1B and D2 receptor mRNAs in Area $\mathrm{X}$, striatum and the ratio of the $\mathrm{X} / \mathrm{St}$ expression in relation to the motif length (mean motif duration was quantified from the first 20 motifs on the three measured days) $(n=19$; one outlier with extremely long motif length $2167.6 \mathrm{~ms}$ and two males that were never singing were excluded from the analyses). $O D_{\mathrm{X}}$ : optical density in Area X; $\mathrm{OD}_{\mathrm{St}}$ : optical density in striatum. 
outside of a breeding context. Dopamine agonists induce and antagonists suppress singing in starling males in the presence of females (Schroeder and Riters 2006) and VTA/SNc lesions decrease female-directed but not undirected song rate in male zebra finch (Hara et al. 2007). Therefore motivation to sing is probably more related to VTA/SNc and the song production might be related to dopamine receptor activation in the motor pathway but not in Area X.
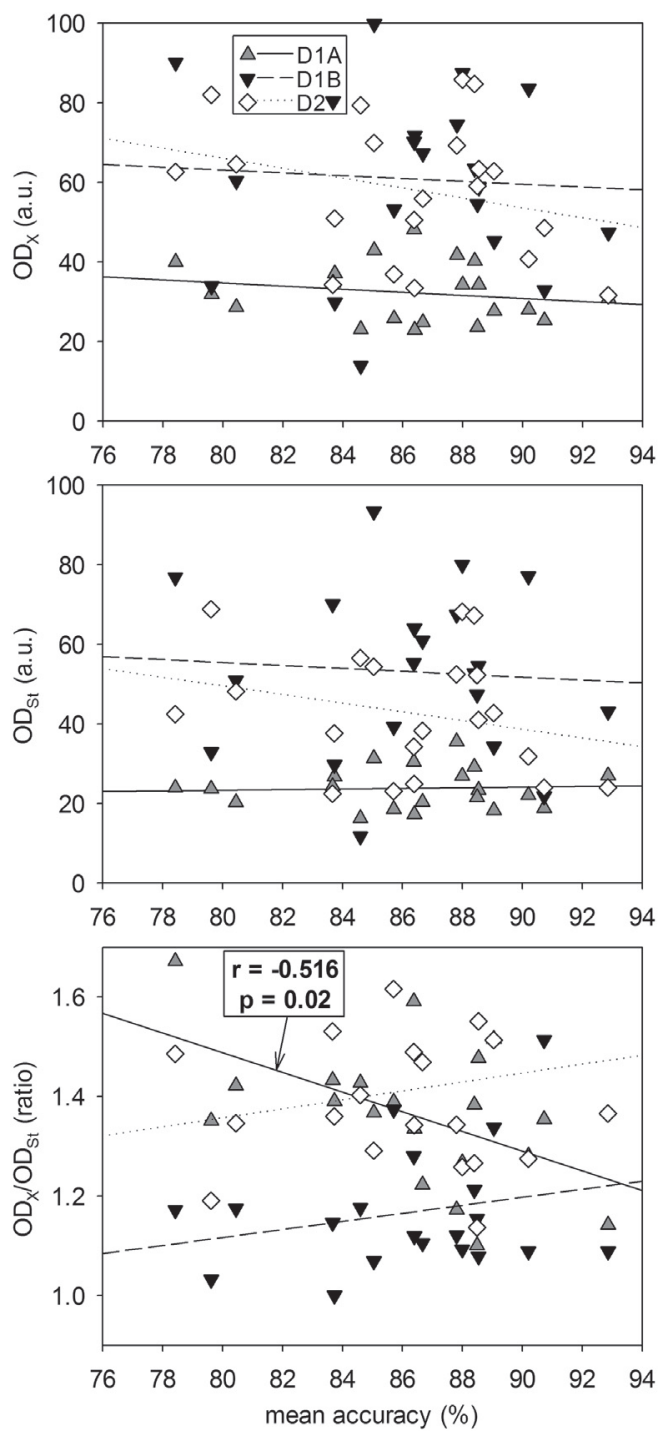

Figure 5. Expression of D1A, D1B and D2 receptor mRNAs in Area $\mathrm{X}$, striatum and the ratio of the $\mathrm{X} / \mathrm{St}$ expression in relation to mean accuracy (calculated from 10 comparisons of randomly selected pairs of motifs from songs sang during the first hour of singing on three different days) ( $n=20$; two males that were never singing were excluded from the analyses). $\mathrm{OD}_{\mathrm{X}}$ : optical density in Area X; $\mathrm{OD}_{\mathrm{St}}$ : optical density in striatum.

\section{Dopamine receptor expression in relation to song variability}

We found lower D1A and higher D2 receptor expression in Area $\mathrm{X}$ relative to the surrounding striatum of zebra finch males singing stereotyped as compared to variable song (in the first case variability expressed in terms of accuracy and in the second case as sequential match). Although adult "crystallized" song is a well-learned motor skill, there still remains small variation. Recent studies in zebra finch
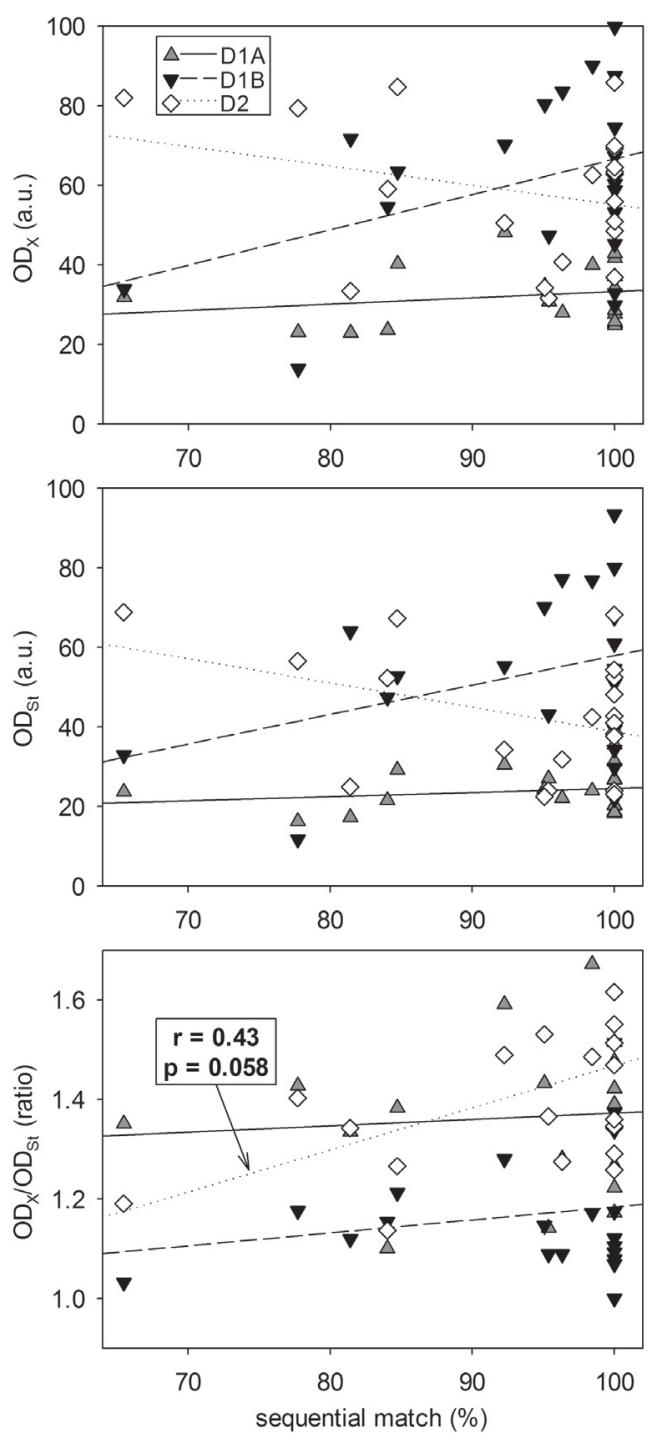

Figure 6. Expression of D1A, D1B and D2 receptor mRNAs in Area $\mathrm{X}$, striatum and the ratio of the $\mathrm{X} / \mathrm{St}$ expression in relation to sequential match (calculated from 10 comparisons of randomly selected pairs of motifs from songs sang during the first hour of singing on three different days) $(n=20$; two males that were never singing were excluded from the analyses). $\mathrm{OD}_{\mathrm{X}}$ : optical density in Area X; OD ${ }_{S t}$ : optical density in striatum. 
suggest that residual variability in adult song might reflect continuous maintenance and optimization of song (Kao et al. 2005; Sakata et al. 2008). Our results imply that dopamine receptors belonging to families with opposing functions in mammals (Kebabian and Calne 1979) as well as in birds (Ding and Perkel 2002) could be involved in opposing features of song.

We do not know if changes in densities of dopamine receptors are involved also in song learning when in zebra finch it is transformed from variable to stereotyped version (Tchernichovski et al. 2001; Liu et al. 2004). The computational model of birdsong learning assumes that the striatal Area $\mathrm{X}$ receiving midbrain dopaminergic projections provides teaching signal for song learning (Doya and Sejnowski 1995). Neural mechanisms mediating behavioural plasticity are under extensive study where long-lasting activity-dependent changes in synaptic strength play a critical role. Activity-dependent synaptic plasticity in zebra finch Area X was shown to require both activation of D1-like dopamine receptors and N-methyl-D-aspartate (NMDA) receptors (Ding and Perkel 2002; Ding et al. 2003). Leblois and co-authors (2010) showed that dopamine increases intrinsic activity of Area X output neurons through D1-like dopamine receptors, and decreases the response of Area $\mathrm{X}$ neurons to HVC stimulation. The changes in D1A and D2 dopamine receptor densities related to song variability suggest that part of the neuronal plasticity responsible for behavioural differences is associated with regulation of dopamine receptors.

Overall, our findings indicate that the expression of distinct dopamine receptors is related to song variability/stereotypy rather than to quantitative parameters of the zebra finch song and that D1A and D2 mediate opposite functions. These results also suggest that part of the corticostriatal synaptic plasticity responsible for song learning and maintenance can be due to dopamine receptor regulation.

Acknowledgement. This research was supported through grants from the National Institutes of Health, NIDCD and Fogarty International Research Collaboration Award, USA, FIRCA R03TW007615-01, from the Scientific Grant Agency of the Ministry of Education of the Slovak Republic and of Slovak Academy of Sciences, VEGA 2/0189/10, VEGA 2/0192/11 and from the Slovak Research and Development Agency VVCE-0064-07. We would like to thank Helenka Rojcikova for taking care of the birds.

\section{References}

Abramoff M., Magalhaes P., Ram S. (2004): Image processing with ImageJ. Biophotonics Int. 11, 36-43

Antonini A., Leenders K. L., Reist H., Thomann R., Beer H. F., Locher J. (1993): Effect of age on D2 dopamine receptors in normal human brain measured by positron emission tomography and 11C-raclopride. Arch. Neurol. 50, 474-480 http://dx.doi.org/10.1001/archneur.1993.00540050026010

Ball G. F., Casto J. M., Balthazart J. (1995): Autoradiographic localization of DI-like dopamine receptors in the forebrain of male and female Japanese quail and their relationship with immunoreactive tyrosine hydroxylase. J. Chem. Neuroanat. 9, 121-133

http://dx.doi.org/10.1016/0891-0618(95)00075-I

Brainard M. S., Doupe A. J. (2002): What songbirds teach us about learning. Nature 417, 351-358

http://dx.doi.org/10.1038/417351a

Casto J. M., Ball G. F. (1994): Characterization and localization of D1 dopamine receptors in the sexually dimorphic vocal control nucleus, area $\mathrm{X}$, and the basal ganglia of European starlings. J. Neurobiol. 25, 767-780 http://dx.doi.org/10.1002/neu.480250703

Chandhoke V., Southall M., Holt R., Flinn J. M. (2001): Dopamine receptor subtype density as a function of age in Aplysia californica. Comp. Biochem. Physiol. B, Biochem. Mol. Biol. 130, 461-466 http://dx.doi.org/10.1016/S1096-4959(01)00447-X

Dietl M., Palacios J. (1988): Neurotransmitter receptors in the avian brain. I. Dopamine receptors. Brain Res. 439, 354-359 http://dx.doi.org/10.1016/0006-8993(88)91494-1

Ding L., Perkel D. (2002): Dopamine modulates excitability of spiny neurons in the avian basal ganglia. J. Neurosci. 22, 5210-5218

Ding L., Perkel D. J., Farries M. A. (2003): Presynaptic depression of glutamatergic synaptic transmission by D1-like dopamine receptor activation in the avian basal ganglia. J. Neurosci. 23, 6086-6095

Doya K., Sejnowski T. (1995): A novel reinforcement model of birdsong vocalization learning. In: Advances in Neural Information Processing Systems 7 (Eds. G. Tesauro, D. Touretzky, T. Leen), pp. 101-108, MIT Press, Cambridge, MA

Durstewitz D., Kröner S., Güntürkün O. (1999): The dopaminergic innervation of the avian telencephalon. Prog. Neurobiol. 59, 161-195 http://dx.doi.org/10.1016/S0301-0082(98)00100-2

Hara E., Kubikova L., Hessler N. A., Jarvis E. D. (2007): Role of the midbrain dopaminergic system in modulation of vocal brain activation by social context. Eur. J. Neurosci. 25, 3406-3416 http://dx.doi.org/10.1111/j.1460-9568.2007.05600.x

Heimovics S. A., Riters L. V. (2008): Evidence that dopamine within motivation and song control brain regions regulates birdsong context-dependently. Physiol. Behav. 95, 258-266 http://dx.doi.org/10.1016/j.physbeh.2008.06.009

Henry J. M., Filburn C. R., Joseph J. A., Roth G. S. (1986): Effect of aging on striatal dopamine receptor subtypes in Wistar rats. Neurobiol. Aging 7, 357-361 http://dx.doi.org/10.1016/0197-4580(86)90162-4

Hessler N. A., Doupe A. J. (1999a): Social context modulates singing-related neural activity in the songbird forebrain. Nat. Rev. Neurosci. 2, 209-211 http://dx.doi.org/10.1038/6306

Hessler N. A., Doupe A. J. (1999b): Singing-related neural activity in a dorsal forebrain-basal ganglia circuit of adult zebra finches. J. Neurosci. 19, 10461-10481 
Jarvis E. D., Nottebohm F. (1997): Motor-driven gene expression. Proc. Natl. Acad. Sci. U. S. A. 94, 4097-4102 http://dx.doi.org/10.1073/pnas.94.8.4097

Jarvis E. D., Scharff C., Grossman M., Ramos J., Nottebohm F. (1998): For whom the bird sings: context-dependent gene expression. Neuron 21, 775-788 http://dx.doi.org/10.1016/S0896-6273(00)80594-2

Kao M. H., Doupe A. J., Brainard M. S. (2005): Contributions of an avian basal ganglia-forebrain circuit to real-time modulation of song. Nature 433, 638-643 http://dx.doi.org/10.1038/nature03127

Kebabian J. W., Calne D. B. (1979): Multiple receptors for dopamine. Nature 277, 93-96 http://dx.doi.org/10.1038/277093a0

Kubikova L., Turner E. A., Jarvis E. D. (2007): The pallial basal ganglia pathway modulates the behaviorally driven gene expression of the motor pathway. Eur. J. Neurosci. 25, 2145-2160 http://dx.doi.org/10.1111/j.1460-9568.2007.05368.x

Kubikova L., Kostal L. (2010): Dopaminergic system in birdsong learning and maintenance. J. Chem. Neuroanat. 39, 112-123 http://dx.doi.org/10.1016/j.jchemneu.2009.10.004

Kubikova L., Wada K., Jarvis E. D. (2010): Dopamine receptors in a songbird brain. J. Comp. Neurol. 516, 749-769

Leblois A., Wendel B., Perkel D. (2010): Striatal Dopamine Modulates Basal Ganglia Output and Regulates Social Context-Dependent Behavioral Variability through D1 Receptors. J. Neurosci. 30, 5730-5743 http://dx.doi.org/10.1523/JNEUROSCI.5974-09.2010

Lewis J., Ryan S., Arnold A., Butcher L. (1981): Evidence for a catecholaminergic projection to area $\mathrm{X}$ in the zebra finch. J. Comp. Neurol. 196, 347-354 http://dx.doi.org/10.1002/cne.901960212

Liu W. C., Gardner T. J., Nottebohm F. (2004): Juvenile zebra finches can use multiple strategies to learn the same song. Proc. Natl. Acad. Sci. U.S.A. 101, 18177-18182 http://dx.doi.org/10.1073/pnas.0408065101

Meng S. Z., Ozawa Y., Itoh M., Takashima S. (1999): Developmental and age-related changes of dopamine transporter, and dopamine $\mathrm{D} 1$ and $\mathrm{D} 2$ receptors in human basal ganglia. Brain Res. 843, 136-144 http://dx.doi.org/10.1016/S0006-8993(99)01933-2

Missale C., Nash S. R., Robinson S. W., Jaber M., Caron M. G. (1998): Dopamine receptors: from structure to function. Physiol. Rev. 78, 189-225

Nieoullon A., Coquerel A. (2003): Dopamine: a key regulator to adapt action, emotion, motivation and cognition. Curr. Opin. Neurol. 16, S3-9 http://dx.doi.org/10.1097/00019052-200312002-00002

Nottebohm F., Stokes T., Leonard C. (1976): Central control of song in the canary, Serinus canarius. J. Com. Neurol. 165, 457-486 http://dx.doi.org/10.1002/cne.901650405

Person A., Gale S., Farries M., Perkel D. (2008): Organization of the songbird basal ganglia, including area X. J. Comp. Neurol. 508, 840-866 http://dx.doi.org/10.1002/cne.21699
Reeves S., Bench C., Howard R. (2002): Ageing and the nigrostriatal dopaminergic system. Int. J. Geriatr. Psych. 17, 359-370 http://dx.doi.org/10.1002/gps.606

Richfield E. K., Young A. B., Penney J. B. (1987): Comparative distribution of dopamine D-1 and D-2 receptors in the basal ganglia of turtles, pigeons, rats, cats, and monkeys. J. Comp. Neurol. 15, 446-463 http://dx.doi.org/10.1002/cne.902620308

Riters L. V. (2011): Pleasure seeking and birdsong. Neurosci. Biobehav. Rev. 35, 1837-1845 http://dx.doi.org/10.1016/j.neubiorev.2010.12.017

Sakata J. T., Hampton C. M., Brainard M. S. (2008): Social modulation of sequence and syllable variability in adult birdsong. J. Neurophysiol. 99, 1700-1711 http://dx.doi.org/10.1152/jn.01296.2007

Sasaki A., Sotnikova T., Gainetdinov R., Jarvis E. D. (2006): Social context-dependent singing-regulated dopamine. J. Neurosci. 26, 9010-9014 http://dx.doi.org/10.1523/JNEUROSCI.1335-06.2006

Schnabel R., Braun K. (1996): Development of dopamine receptors in the forebrain of the domestic chick in relation to auditory imprinting. An autoradiographic study. Brain Res. 720, 120-130 http://dx.doi.org/10.1016/0006-8993(96)00160-6

Schroeder M. B., Riters L. V. (2006): Pharmacological manipulations of dopamine and opioids have differential effects on sexually motivated song in male European starlings. Physiol. Behav. 88, 575-584 http://dx.doi.org/10.1016/j.physbeh.2006.05.011

Sossinka R., Böhner J. (1980): Song types in the zebra finch Poephila guttata castanotis. Z. Tierpsychol. 53, 123-132

Suhara T., Fukuda H., Inoue O., Itoh T., Suzuki K., Yamasaki T., Tateno Y. (1991): Age-related changes in human D1 dopamine receptors measured by positron emission tomography. Psychopharmacology 103, 41-45

http://dx.doi.org/10.1007/BF02244071

Sun Z., Reiner A. (2000): Localization of dopamine D1A and D1B receptor mRNAs in the forebrain and midbrain of the domestic chick. J. Chem. Neuroanat. 19, 211-224 http://dx.doi.org/10.1016/S0891-0618(00)00069-7

Tchernichovski O., Nottebohm F., Ho C., Pesaran B., Mitra P. (2000): A procedure for an automated measurement of song similarity. Anim. Behav. 59, 1167-1176 http://dx.doi.org/10.1006/anbe.1999.1416

Tchernichovski O., Mitra P. P., Lints T., Nottebohm F. (2001): Dynamics of the vocal imitation process: how a zebra finch learns its song. Science 291, 2564-2569 http://dx.doi.org/10.1126/science.1058522

Teicher M. H., Andersen S. L., Hostetter J. C. (1995): Evidence for dopamine receptor pruning between adolescence and adulthood in striatum but not nucleus accumbens. Dev. Brain Res. 89, 167-172 http://dx.doi.org/10.1016/0165-3806(95)00109-Q

Received: March 19, 2012

Final version accepted: April 26, 2012 